\title{
ANALYSIS OF SPEAKING MATERIAL IN ENGLISH TEXTBOOK AT GRADE XII PUBLISHED BY KEMENDIKBUD 2018
}

\author{
Lusi Tri Utami $^{1}$, Abdul Syahid ${ }^{2}$, Aris Sugianto ${ }^{3}$ \\ 1,2,3 State Islamic Institute Palangka Raya Indonesia \\ ${ }^{1}$ lusi02tu@gmail.com, ${ }^{2}$ abdul.syahid@iain-palangkaraya.ac.id, ${ }^{3}$ aris.sugianto@iain- \\ palangkaraya.ac.id
}

\begin{abstract}
In a learning process of learning English, teaching materials are needed to support the learning process such as textbooks. Therefore, this research analysed English speaking material in "Bahasa Inggris" English textbook for twelfth grade of Senior High School Published by Kemendikbud 2018. The research problem of the study were: (1) What types of speaking material are there in "Bahasa Inggris" English textbook?, and (2) How is the content of the material on speaking English textbook for twelfth grades published by Indonesian government?. Therefore, the purposes of this study were: (1) To describe types of speaking material in "Bahasa Inggris" English Textbook., and (2) To identify the contain of material of speaking skills found in English textbook for twelfth graders published by Indonesian government. In carrying out this research, researcher used a qualitative approach with content analysis method. Data collected by carrying out evaluation checklist, interview, and documentation. The main research findings were: (1) The speaking materials contained in "Bahasa Inggris" English textbooks for twelfth graders published by Indonesian governmentcontains material in the form of dialogue, and (2) The speaking material in the book can help students based on the teacher's perspective and evaluation checklists.
\end{abstract}

Keywords: Speaking Material, Textbook Analysis, English Textbook

\section{INTRODUCTION}

Textbooks is one of the main things that are important for the learning process and are supported by explanations from the teacher.According to Stará, Chvál, \& Starý (2017), textbooks play a prominent role in the teaching or learning process. Furthermore, one of the primary functions of textbooks is to make established information accessible and visible to learners in a select, easy, and structured manner. What teachers teach and what students understand is influenced by the material of English language textbooks.

Textbook is one of the most important for learning procces. Robiyati (2015) states that the significant media ultimately coursebook ought to be acceptable and appropriate with the condition, levels of the understudies, and generally simple to read and understand.This subject book can provide understanding in addition to the teacher's explanation. It can be seen from the English language, which is not a language mastered by students. Therefore textbook is a way to help in the student learning process, especially in English subjects.

Mayangsari, Nurkamto, \& Supriyadi (2018) explains about Students in the Indonesian educational system are also required to have a textbook. The textbooks for all subjects are provided by the government. For each subject, each student receives one textbook. Instead of 
focusing on the culture of English-speaking countries, Indonesian students should concentrate on talking about and debating Indonesian culture in English.

Speaking is a useful ability to have when studying a language. It includes communicative efficiency as well as other essential aspects including pronunciation, intonation, grammar, vocabulary, and so on. They ought to be instructed in any language sorting out some way to prepare the understudies to use the target language to pass on.Speaking is one of four skills that important to learn. In a real-life environment, the learners will be judged most on their ability to talk. It is an integral aspect of daily interaction, and most people's first impressions are focused on their ability to communicate clearly and fluently.Thus, the teachers have an obligation to set up the students however much as could reasonably be expected to have the option to communicate in English in the genuine circumstance.

Based on the explanation, the researcher analyzed the speaking material in English textbook. The analyzing books is done to determine the effect on student development. The material in the book can develop students' speaking skills and see the quality of the book based on the views of the teacher who uses the English textbook

\section{METHOD}

This research used qualitative study. Since this research is focused on analyzing the content of a textbook, specifically in the form of a document book.According to Ary, Jacobs, Sorensen, \& Razavieh (2010, p. 648) a qualitative research is approach that investigates phenomena in their natural environment without making any assumptions.

The researcher's instruments were three instruments which were interview, evaluation checklist and documentation. This research used evaluation checklist instrument based on the English textbook evaluation and interview two teachers. It saw in table below:

a. Evaluation Checklist

\section{Table 1. Evaluation Checklist}

\begin{tabular}{|c|c|c|c|c|c|}
\hline \multicolumn{6}{|l|}{$\begin{array}{l}\text { I. General attributes } \\
\text { A. The book in relation to syllabus and curriculum }\end{array}$} \\
\hline 1. It matches to the specifications of the syllabus. & (0) & (1) & (2) & (3) & (4) \\
\hline \multicolumn{6}{|l|}{ B. Methodology } \\
\hline 2. The activities can be exploited fully and can embrace the various & (0) & (1) & (2) & (3) & (4) \\
\hline methodologies in ELT. & (0) & (1) & (2) & (3) & (4) \\
\hline \multicolumn{6}{|l|}{ 3. Activities can work well with methodologies in ELT. } \\
\hline \multicolumn{6}{|l|}{ C. Suitability to learners } \\
\hline 4. It is compatible to background knowledge and level of students. & (0) & (1) & (2) & (3) & (4) \\
\hline 5. It is compatible to the socio-economic context. & (0) & (1) & (2) & (3) & (4) \\
\hline 6. It is culturally accessible to the learners. & (0) & (1) & (2) & (3) & (4) \\
\hline 7. It is compatible to the needs of the learners. & (0) & (1) & (2) & (3) & (4) \\
\hline \multicolumn{6}{|l|}{ D. Physical and utilitarian attributes } \\
\hline 8. Its layout is attractive. & (0) & (1) & (2) & (3) & (4) \\
\hline 9. It indicates efficient use of text and visuals. & (0) & (1) & (2) & (3) & (4) \\
\hline 10. It is durable. & (0) & (1) & (2) & (3) & (4) \\
\hline 11. It is cost-effective. & (0) & (1) & (2) & (3) & (4) \\
\hline 12. Its size is appropriate. & (0) & (1) & (2) & (3) & (4) \\
\hline 13. The printing quality is high. & (0) & (1) & (2) & (3) & (4) \\
\hline \multicolumn{6}{|l|}{ II. Learning-teaching content } \\
\hline \multicolumn{6}{|l|}{ A. General } \\
\hline 14. Tasks move from simple to complex. & (0) & (1) & (2) & (3) & (4) \\
\hline 15. Task objectives are achievable. & (0) & (1) & (2) & (3) & (4) \\
\hline 16. Cultural sensitivities have been considered. & (0) & (1) & (2) & (3) & (4) \\
\hline
\end{tabular}




\begin{tabular}{|c|c|c|c|c|c|}
\hline 17. The language in the textbook is natural and real. & (0) & (1) & (2) & (3) & (4) \\
\hline 18. The situations created in the dialogues sound natural and real. & (0) & (1) & (2) & (3) & (4) \\
\hline 19. The material is up-to-date. & (0) & (1) & (2) & (3) & (4) \\
\hline 20. It covers a variety of topics from different fields. & (0) & (1) & (2) & (3) & (4) \\
\hline 21. The book contains fun elements. & (0) & (1) & (2) & (3) & (4) \\
\hline \multicolumn{6}{|l|}{ C. Speaking } \\
\hline 22. Activities are developed to initiate meaningful communication. & (0) & (1) & (2) & (3) & (4) \\
\hline 23. Activities are balanced between individual response, pair work and group work. & (0) & (1) & (2) & (3) & (4) \\
\hline 24. Activities motivate students to talk. & (0) & (1) & (2) & (3) & (4) \\
\hline \multicolumn{6}{|l|}{ D. Pronunciation } \\
\hline 25. It is contextualized. & (0) & (1) & (2) & (3) & (4) \\
\hline 26. It is easy to learn & (0) & (1) & (2) & (3) & (4) \\
\hline \multicolumn{6}{|l|}{ E. Exercises } \\
\hline 27. They have clear instructions. & (0) & (1) & (2) & (3) & (4) \\
\hline 28. They are adequate. & (0) & (1) & (2) & (3) & (4) \\
\hline 29. They help students who are under/over-achievers. & (0) & (1) & (2) & (3) & (4) \\
\hline
\end{tabular}

b. Question of interview transcript

1. As an English teacher, does English textbook "Bahasa Inggris" has been appropriate with students need? if yes, why? if no, why?

2. Is there any decent speaking content in the English textbook "Bahasa Inggris" for the 12th grade of Senior High School? If this is the case, please explain why.

3. By using "Bahasa Inggris" for twelvegrade of Senior High School, do the speaking skill can improving with their material? and please give the reasons.

4. Do the practice activities if yes, why ? if no, why?

5. Do you accept, as a teacher, that the school should use the English textbook "Bahasa Inggris" for the 12th grade of Senior High School? If so, what is the reason? If not, what is the reason?

\section{RESULTS AND DISCUSSION}

\section{Results}

\section{a. Result of Interview}

For interview, the researcher had two people as interviewee. They are a teacher of twelve grade in SMAN 3 Sampit, and they had information that related with what the researcher found out.

Data of first instrument was the result of interview. The first interviewee was Mam ETR, and she answered :

1. Yes, I think it's appropriate because In the book, there are all the skills that can help students in the learning process. All of these materials can help students understand the lesson

2. In my opinion this book has good speaking material, where in this book there are statements or exercises for students to improve their speaking skills.

3. In my opinion, the speaking material in the book can improve students' abilities, where there is a dialogue or discussion in the book that can be used to help students reach their full potential.

4. As has been said before that in this book there are dialogues or conversations which can help students understand the material easily, besides, the question is practiced in front of the class as a form of speaking practice

5. Yes, I strongly agree because the book includes all skills, especially speaking skills, The questions contained in the book also helped students because they were easy to understand and could be used as exercises 
The second interviewee was Mam JW, and she answered:

1. I think this book is appropriate because there are skills that students need to increase their ability to speak English.

2. In this book, there are speaking materials which are mostly conversational, in my opinion that is a good thing, conversation can spur students' speaking ability with fellow friends. But besides that, there are also texts that trigger students' speaking skills besides dialogue.

3. Using this book students can develop their speaking skills through existing questions or exercises

4. This book has practice questions in the form of conversations where this must be practiced directly, for example with classmates, this can make students develop especially in speaking ability.

5. I agree, This book can be used to help students understand or improve their skills, and the content is comprehensive enough to aid the learning process.

\section{b. Result of Evaluation Checklist}

Here, the result of evaluation checklist consisted of textbook and evaluated by two teachers.

Table 2. The Result of Evaluation ChecklistFrom Mam ETR CATEGORY COMMENT

I. General attributes

A. The book in relation to syllabus and curriculum

1. It matches to the specifications of the syllabus.

\section{B. Methodology}

2. The activities can be exploited fully and can embrace the various

methodologies in ELT.

3. Activities can work well with methodologies in ELT.

C. Suitability to learners

\begin{tabular}{|c|c|c|c|c|c|c|}
\hline $\begin{array}{l}\text { 4. It is compatible to background knowledge and } \\
\text { level of students. }\end{array}$ & (0) & (1) & (2) & (3) & (4) & $\begin{array}{l}\text { In accordance with } \\
\text { the student's previous }\end{array}$ \\
\hline 5. It is compatible to the socio-economic context. & (0) & (1) & (2) & (3) & (4) & knowledge and meet \\
\hline 6. It is culturally accessible to the learners. & (0) & (1) & (2) & (3) & (4) & the needs of students \\
\hline 7. It is compatible to the needs of the learners. & (0) & (1) & (2) & (3) & (4) & \\
\hline \multicolumn{7}{|l|}{ D. Physical and utilitarian attributes } \\
\hline 8. Its layout is attractive. & (0) & (1) & (2) & (3) & (4) & book \\
\hline 9. It indicates efficient use of text and visuals. & (0) & (1) & (2) & (3) & (4) & standard quality with \\
\hline 10. It is durable. & (0) & (1) & (2) & (3) & (4) & good quality and \\
\hline 11. It is cost-effective. & (0) & (1) & (2) & (3) & (4) & attractive \\
\hline 12. Its size is appropriate. & (0) & (1) & (2) & (3) & (4) & \\
\hline 13. The printing quality is high. & (0) & (1) & (2) & (3) & (4) & \\
\hline
\end{tabular}

\section{Learning-teaching content}

A. General

14. Tasks move from simple to complex.

15. Task objectives are achievable.

16. Cultural sensitivities have been considered.

17. The language in the textbook is natural and real.

18. The situations created in the dialogues sound natural and real.

19. The material is up-to-date.

20. It covers a variety of topics from different fields.

21. The book contains fun elements.

This book contains assignments from various fields but sometimes there are things that are not familiar to students 


\begin{tabular}{|c|c|c|c|c|c|c|}
\hline $\begin{array}{l}\text { C. Speaking } \\
\text { 22. Activities are developed to initiate meaningful } \\
\text { communication. } \\
\text { 23. Activities are balanced between individual } \\
\text { response, pair work and group work. } \\
\text { 24. Activities motivate students to talk. }\end{array}$ & (0) & (1) & (2) & (3) & (4) & $\begin{array}{l}\text { The speaking activity } \\
\text { section contains a } \\
\text { balance of individual } \\
\text { responses and group } \\
\text { work }\end{array}$ \\
\hline $\begin{array}{l}\text { D. Pronunciation } \\
\text { 25. It is contextualized. } \\
\text { 26. It is easy to learn }\end{array}$ & $\begin{array}{l}\text { (1) } \\
\text { (0) }\end{array}$ & $\begin{array}{l}\text { (1) } \\
\text { (1) }\end{array}$ & $\begin{array}{l}\text { (2) } \\
\text { (2) }\end{array}$ & $\begin{array}{l}\text { (3) } \\
\text { (3) }\end{array}$ & $\begin{array}{l}\text { (4) } \\
\text { (4) }\end{array}$ & $\begin{array}{l}\text { Many words are easy } \\
\text { to pronounce }\end{array}$ \\
\hline $\begin{array}{l}\text { E. Exercises } \\
\text { 27. They have clear instructions. } \\
\text { 28. They are adequate. } \\
\text { 29. They help students who are under/over- } \\
\text { achievers. }\end{array}$ & $\begin{array}{l}\text { (0) } \\
\text { (0) } \\
\text { (0) }\end{array}$ & $\begin{array}{l}\text { (1) } \\
\text { (1) } \\
\text { (1) }\end{array}$ & $\begin{array}{l}\text { (2) } \\
\text { (2) } \\
\text { (2) }\end{array}$ & $\begin{array}{l}\text { (3) } \\
\text { (3) } \\
\text { (3) }\end{array}$ & $\begin{array}{l}\text { (4) } \\
\text { (4) } \\
\text { (4) }\end{array}$ & $\begin{array}{l}\text { The book has clear } \\
\text { instructions for each } \\
\text { section of the } \\
\text { assignment }\end{array}$ \\
\hline
\end{tabular}

Table 3. The Result of Evaluation ChecklistFrom Mam JW

\begin{tabular}{l} 
CATEGORY \\
\hline I. General attributes \\
A. The book in relation to syllabus and curriculum
\end{tabular}

1. It matches to the specifications of the syllabus. COMMENT

(2) (1) (2) (3) (4) This book is in accordance with the existing curriculum and syllabus

\section{B. Methodology}

2. The activities can be exploited fully and can embrace the various

methodologies in ELT.

3. Activities can work well with methodologies in ELT.

C. Suitability to learners

4. It is compatible to background knowledge and level of students.

5. It is compatible to the socio-economic context.

6. It is culturally accessible to the learners.

7. It is compatible to the needs of the learners.

D. Physical and utilitarian attributes

8. Its layout is attractive.

9. It indicates efficient use of text and visuals.

10. It is durable.

11. It is cost-effective.

12. Its size is appropriate.

13. The printing quality is high.

II. Learning-teaching content

A. General

14. Tasks move from simple to complex.

15. Task objectives are achievable.

16. Cultural sensitivities have been considered.

17. The language in the textbook is natural and real.

18. The situations created in the dialogues sound natural and real.

19. The material is up-to-date.

20. It covers a variety of topics from different fields.

21. The book contains fun elements.

C. Speaking

22. Activities are developed to initiate meaningful communication.

23. Activities are balanced between individual response, pair work and group work.

24. Activities motivate students to talk.

(1) (1) (2) (3) (4)
the method used by the teacher can be adjusted to the method in ELT

(1) (1) (2) (3) (4)

\begin{tabular}{|c|c|c|c|c|c|}
\hline (0) & (1) & (2) & (3) & (4) & und of \\
\hline & & & & & students' \\
\hline (0) & (1) & (2) & (3) & (4) & influences \\
\hline (0) & (1) & (2) & (3) & (4) & continuation of the \\
\hline (0) & (1) & (2) & (3) & (4) & learning context \\
\hline
\end{tabular}

(2) (1) (2) (3) (4) seen in terms of form,

(0) (1) (2) (3) (4) this book is standard

(a) (1) (2) (3) (4)

(0) (1) (2) (3) (4)

(0) (1) (2) (3) (4)

(0) (1) (2) (3) (4) this book is standard

\begin{tabular}{|c|c|c|}
\hline (1) & (2) & (3) \\
\hline (1) & (2) & (3) \\
\hline (1) & (2) & (3) \\
\hline (1) & (2) & (3) \\
\hline (1) & (2) & (3) \\
\hline (1) & (2) & (3) \\
\hline (1) & (2) & (3) \\
\hline (1) & (2) & (3) \\
\hline
\end{tabular}

This book contains quite a complete set of things that can be found in everyday life, but some that have never been known

speaking activity can (2) (1) (2) (3) (4) convey a meaning that can make (2) (1) (2) (3) (4) students respond well (2) (1) (2) (3) (4) 


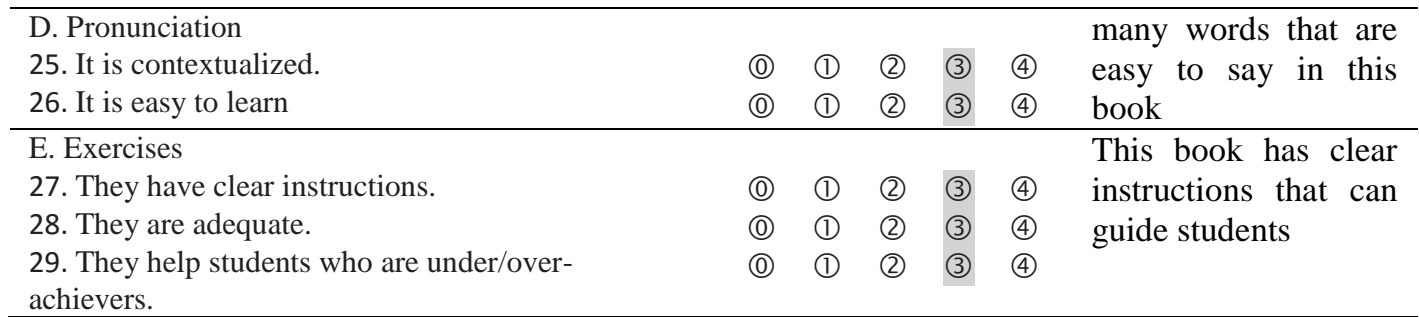

The table interprets result data of interview and evaluation checklist by two teachers that used the "Bahasa Inggris" English textbook.

\section{Discussion}

This section of the research will address the findings of the research, which were gathered from an English textbook called "Bahasa Inggris" for the twelve grades of Senior High School.The discussion focused on Centered on a teacher's viewpoint and an assessment checklist, speaking content in the English textbook "Bahasa Inggris" for the 12th grade of Senior High School. The discussion was divided into two major points: First, types of speaking material are there in the "Bahasa Inggris" English textbook. This was conducted to know the type of speaking material in that English textbook. Second, the content of the material on speaking English textbook for twelfth grades published by the Indonesian government. This was done to describe the contained skills based on teacher perspective supported with an evaluation checklist.

The first interviewee said the English textbook "Bahasa Inggris" for twelfth grade has a material type in the form of a dialog. Whereas, not all schools use books published by the Indonesian government, even though these books can help students. This book not only has material on speaking skills but covers all existing skills. The speaking material in this book is also supported by the pronunciation part which can help students in pronunciation while speaking.

The second interviewee said the English textbook "Bahasa Inggris" for twelfth grade has a material type in the form of a dialog. Then, this textbook started from basic material like pronunciation practice because in speaking, of course, students must say the word or sentence correctly to convey the meaning correctly. So, it is easy for students to follow it. Moreover, speaking material in this English textbook is balanced in each chapter. Then, all materials related to daily life or contextual.

From two interviewees The study discovered that the English textbook "Bahasa Inggris" for the twelfth grade of Senior High School has English speaking material. Then, this textbook has a dialog for the type of speaking material, and suitable to use for Senior High School's twelfth grade.

The distinguish from previous study, first Kurkgöz (2009) found that to meet MNE curriculum goals so the textbooks must be carefully designed and young learners become interested and need on textbooks. Second, AbdelWahab (2013) focused on literature on English textbook evaluation. Next, Anjaneyulu (2014) found a book revision should constantly update the content according to the context of teaching and learners need. The last is Salihah \& Aris (2017) showed that there were only a few authentic materials and four skills in the textbook Intan Pariwara, especially Buku Bahasa Inggris Mata Pelajaran Wajib Kelas XI compiled by Bachtiar Bima M and Cicik Kurniawati for semester 1. As a result, the researcher's thesis was distinct from previous studies. 
Finally, it can be concluded that The English textbook "Bahasa Inggris" for Senior High School's twelfth grade contains four English skills, they are: listening, reading, writing, and especially for English speaking skill material. Furthermore, most of this English textbook has included the perspective from teachers and supported by an evaluation checklist. So, the English textbook "Bahasa Inggris" was published by the Indonesian Government is suitable to use for Senior High School's twelfth grade. Moreover, the similarities with previous study was the researcher used textbook as a source of data.

\section{CONCLUSION}

There are two results from analyzed the data. First, the type of speaking material in the form of dialogue and filling questions. was discovered in the Indonesian Government's English textbook "Bahasa Inggris" for the twelfth grade of Senior High School.

Second, English speaking material showed in teachers perspective and evaluation checklist for textbook. First, we will listen carefully to our teacher read the greetings. Second, the teacher tells some vocabulary related to the material or brainstorming before entering the subject material. Next, we will repeat the some word to pronunciation practice. Then, we will read the conversation with friends and after that fill in some questions related to the conversation.

\section{ACKNOWLEDGMENTS}

Alhamdulillahirabbil 'alamin, the researcher thanks to Allah SWTfor his blessing, love and mercy her whole life while for finishing this article. Also, Sholawat and Salam to our Prophet Muhammad SAW that bring our life from the darkness to brightness. This article entitled "Analysis of Speaking Material In English Textbook At Grade XII Published By Kemendikbud 2018" is submitted as the final requirement in accomplishing research paper at English Education Study Program State Islamic Institute of Palangka Raya.

\section{REFERENCES}

AbdelWahab, M. M. (2013). Developing an English language textbook evaluative checklist. IOSR Journal of Research \& Method in Education, 1(3), 55-70.

Anjaneyulu, T. (2014). A critical analysis of the English language textbooks in Andhra Pradesh, India. ELT Research Journal, 3(4), 181-200.

Ary, D., Jacobs, L. C., Sorensen, C., \& Razavieh, A. (2010). Introduction to Research in Education. Belmont: Wadsworth Publishing.

Kırkgöz, Y. (2009). Evaluating the English textbooks for young learners of English at Turkish primary education. Procedia-Social and Behavioral Sciences, 1(1), 79-83.

Mayangsari, L., Nurkamto, J., \& Supriyadi, S. (2018). Cultural content: An analysis of EFL textbook in Indonesia. International Journal of Scientific and Research Publications (IJSRP), 8(11), 192-199.

Robiyati, N. (2015). An analysis of reading questions in the textbook. Doctoral dissertation, IAIN Palangka Raya.

Salihah, P. R., \& Aris, S. (2017). Authentic Materials Exised in the Textbook by Intan Pariwara for Senior High School. International Conference on English Teaching, 299-320.

Stará, J., Chvál, M., \& Starý, K. (2017). The role of textbooks in primary education. EPedagogium, 17(4), 60-69. 